\title{
Morphological, physical and pedogenetic attributes related to water yield in small watersheds in Guarapari/ES, Brazil ${ }^{l}$
}

\author{
Alexson de Mello Cunha², João Luiz Lani ${ }^{3}$, Liovando Marciano da Costa ${ }^{4}$,Elpídio Inácio Fernandes Filho ${ }^{3}$, \\ Eufran Ferreira do Amaral
}

\begin{abstract}
Soil characteristics related to the genesis, land use and management are important factors in water dynamics in watersheds. This study evaluated physical, morphological and pedogenetic attributes related to water yield potential in small watersheds in Guarapari, ES, Brazil. The following representative profiles were selected, morphologically described and sampled in area of Atlantic Forest domain: Lithic Udifolists, Oxyaquic Udifluventes, Typic Paleudults, Typic Hapludults, Typic Hapludox, Oxic Dystrudepts and Typic Endoaquents. Samples were collected in the soil profiles for physical analysis. Measurements of field-saturated hydraulic conductivity and soil penetration resistance were perfomed in some profiles, which were under different uses. The Endoaquents of Limão Creek can be considered efficient as temporary water reservoirs. However, the use of artificial drainage tends to reduce this effect. Differential erosion was detected by the sand texture on the surface of the Typic Paleudults due to the low degree of clay flocculation, slope, high resistance to the penetration and low hydraulic conductivity of the Bt horizon, making it necessary to adopt soil management practices to increase the water infiltration. Under pasture, mainly in the cattle trails where the trampling is more intense, there was high resistance to penetration in the superficial layers of the Typic Hapludults. The Typic Hapludox have the greatest potential for water yield in the small watersheds because of its greater extent in the headwaters and their morphological and physical characteristics, which can result in increased aquifer recharge.
\end{abstract}

Key words: Land use, water infiltration, soil classes.

\section{RESUMO}

\section{Atributos morfológicos, físicos e pedogenéticos relacionados com a "produção de água" em microbacias do município de Guarapari, ES, Brasil}

As características dos solos relacionadas com a gênese, uso e manejo adotados são importantes fatores na dinâmica da água em bacias hidrográficas. Neste trabalho, avaliaram-se alguns atributos morfológicos, físicos e pedogenéticos, relacionados com o potencial de produção de água em microbacias do município de Guarapari, ES. Foram selecionados e descritos morfologicamente perfis de solo representativos da área de domínio de Mata Atlântica: Neossolos Litólicos e Flúvicos, Argissolos Vermelho e Amarelo, Latossolos Vermelho e Amarelo, Cambissolo Háplico e Gleissolo Háplico. Amostras de solo foram coletadas nos perfis para realização de análises físicas. Condutividade hidráulica e resistência à penetração do solo foram determinadas em campo em alguns perfis, os quais se encontravam sob diferentes usos. Os Gleissolos do córrego do Limão podem ser considerados eficientes como reservatórios

\footnotetext{
Recebido para publicação em 01/12/2010 e aprovado em 20/07/2011

${ }^{1}$ Part of the Master Dissertation presented to the Universidade Federal de Viçosa for the first author.

2 Agronomist Engineer, Master of Science. Universidade Federal de Viçosa. Av. Peter Henry Rolfs, s/n, 36570-000, Viçosa, MG, Brazil. alexson.cunha@ vta.incra.gov.br

${ }^{3}$ Agronomist Engineers, Doctor Science. Universidade Federal de Viçosa, Departamento de Solos. Av. Peter Henry Rolfs, s/n, 36570-000, Viçosa, MG, Brazil. lani@ufv.br; elpidio@ufv.br

${ }^{4}$ Agronomist Engineer, Ph. Doctor. Universidade Federal de Viçosa, Departamento de Solos. Av. Peter Henry Rolfs, s/n, 36570-000, Viçosa, MG, Brazil. liovando@ufv.br

${ }_{5}^{5}$ Agronomist Engineer, Doctor Science. Researcher of Centro de Pesquisa Agroflorestal do Acre. Embrapa Acre. Caixa Postal 321, 69908-970, Rio Branco, AC, Brazil.
} 
temporários de água. Entretanto, o uso de drenagem artificial tende a reduzir este efeito. Erosão diferencial foi verificada pela textura arenosa na superfície do Argissolo Vermelho em razão do baixo grau de floculação das argilas, declividade do terreno, alta resistência à penetração e baixa condutividade hidráulica do horizonte $\mathrm{Bt}$, tornando necessária a adoção de práticas de manejo que aumentem a infiltração de água neste solo. Sob pastagem, principalmente nas trilhas de gado onde o pisoteio é mais intenso, verificou-se elevada resistência à penetração nas camadas superficiais do Argissolo Amarelo. Os Latossolos Amarelos são de maior potencial para a produção de água nas microbacias, por sua maior extensão nas cabeceiras e suas características morfológicas e físicas, as quais podem resultar em maior recarga de aquíferos.

Palavras-chave: Uso do solo, infiltração de água, classes de solo.

\section{INTRODUCTION}

Recently, increased attention has been given to aspects of soil involved in the hydrological cycle, in view of the world population growth and forecast of water shortages in many countries. In the first half of the twentieth century, the conservation and preservation of the physical resources that are related to the water became a real concern. For this reason, soil studies directed toward this issue have become a necessity.

The soil has a function as water reservoir and studying the water dynamics in the soil is essential for the understanding of the role of the land surface in the hydrological cycle (Resende et al. 1999a, b). The factors that affect water infiltration are related to soil characteristics, its management and the external environment, such as rainfall characteristics, antecedent moisture conditions, use and management history, vegetation, biological activity, surface roughness, slope and shape of the landscape, among others (Reichert et al., 1992). Some hydrological studies have shown that water and physical attributes of different morphological classes of soil are important in determining the flow of water in the soil and potential groundwater recharge (Lin et al., 1999, Maki et al. 2007; Menezes et al., 2009).

Other factors related to soil classes, such as texture and structure, significantly influence infiltration and water runoff (Resende et al. 1999a; Costa et al., 2001). In this context, besides the influence of use and management, soils of different classes and with intrinsic characteristics can result in different rates of infiltration, and thus aquifer recharge, affecting the quality and quantity of water produced in a given river basin.

This work evaluated morphological, physical and pedogenetic attributes related to the potential of water production in two watersheds in area of Atlantic Forest domain, in Guarapari, ES, Brazil.

\section{MATERIAL AND METHODS}

\section{Area characterization}

The study area is located in the municipality of Guarapari, ES, between the parallels $20^{\circ} 33^{\prime}$ and $20^{\circ} 42^{\prime}$ south latitude and between the meridians $40^{\circ} 31^{\prime}$ and $40^{\circ} 37^{\prime}$ west longitude, which belongs to the metropolitan Vitória, according to the Regional Division of the State of Espirito Santo (IPES, 2002). The studied area refers to the watershed of the Oratório and Limão Creeks, which fall into the Guarapari basin.

The climate (Koppen) is classified as Aw - hot and humid with rainy summer in the coastal lowlands (Coastal Tablelands), and Am - hot and humid with less pronounced dry season, in the mountains and slopes above $300 \mathrm{~m}$ (Embrapa, 1978). The altitudes range from sea level to $775 \mathrm{~m}$ and average annual rainfall reaches $1,239 \mathrm{~mm}$ (IPES, 2002).

The area consists, for the most part, of gneisses and granites (Paraiba do Sul Complex, and to a lesser extent, the Espírito Santo Intrusive Suite) and a narrow strip of Tertiary sediments (Barreiras Group) and Quaternary, which sometimes come into contact with the sea (Embrapa, 1978, Brasil, 1983).

The area's natural vegetation is dense rain forest, but currently dominated by secondary vegetation at different successional stages, agricultural crops and, mainly, pasture (Brasil, 1983).

\section{Soil Survey}

The major classes of soil in the study area were characterized by Cunha (2003), and defined with field and laboratory observations, according to standards, criteria and nomenclature adopted by Embrapa (2006).

Soil mapping was performed by analysis of unconventional aerial photographs and their digital mosaic, using the software Idrisi 32 and ArcView 3.2a (Cunha et al., 
2006). Determination of the relief phases was based on the slope classes generated by the software Idrisi 32, from the digitization of contour lines of planialtimetric maps from IBGE - Sheet SF - 24 - V - A - VI - 2.

\section{Soil characterization}

The area was surveyed for identification of soil mapping units and their strata, vegetation and land use. Considering its representation in the area and the difficulty of standardizing the vegetation, there were selected eight soil profiles under different uses (pasture and coffee intercropped with banana). Selected profiles were morphologically described (Table 1) and sampled according to Lemos \& Santos (1996). Soils were classified, according to the Brazilian Soil Classification System (Embrapa, 2006) and their U.S. Soil Taxonomy (USDA, 2010) nearest equivalent in brackets: Neossolo Litólico Distrófico hístico - RLi (Lithic Udifolists), Argissolo Vermelho Distrófico típico - PVd (Typic Paleudults), Latossolo Vermelho Distrófico típico - LVd (Typic Hapludox), Cambissolo Háplico Tb Distrófico típico CXbd (Oxic Dystrudepts), Neossolo Flúvico Tb Distrófico gleissólico - RYbd (Oxyaquic Udifluventes), Argissolo Amarelo Distrocoeso latossólico - PAd (Typic Hapludults), Gleissolo Háplico Tb Distrófico típico - GXbd (Typic Endoaquents) e Latossolo Amarelo Distrófico típico - LAd (Typic Hapludox). The Oxisols and Ultisols were described in road cut and the other profiles in mini-trenches, being located in an east-west transect, comprising parts of the Barreiras Group and Cristaline Complex. Soil samples for physical analysis were collected in surface and subsurface diagnostic horizons of each profile studied.

Soil physical characterization consisted of the following analysis: texture, water-dispersible clay (pipette method), bulk density (volumetric ring method), particle density (bottle method), total porosity calculated based on soil density and particle density; moisture equivalent determined in pre-saturated soil sample $(<2 \mathrm{~mm})$; water retention at tensions of $0.01 \mathrm{MPa}$ and $1.5 \mathrm{MPa}$, according to Embrapa (1997).

Penetration resistance and soil hydraulic conductivity were determined in the field to characterize the surface and subsurface diagnostic horizons of selected profiles that were deeper and with better internal drainage (LAd, LVd, PVd and PAd). These determinations were carried out in locations close to the profiles described, to prevent changes in soil class or interference due to road cuts. In the case of LAd, it was possible to select a site next to the profile described with secondary forest vegetation as a reference. The PVd profile was described in a patch of soil used with coffee intercropped with banana, and the determinations were made in the space between the rows. In the classes of soil under pasture (LAd, LVd and
PAd), determinations of resistance to penetration were carried out on and between the cattle trail, because of the high lands and the significant presence of these pathways preferred by the cattle.

Measurements of soil penetration resistance in Oxisols and Ultisols were performed at depths from 0 to $0.60 \mathrm{~m}$, in the same day, with three replications, using a Stolf impact cone penetrometer. The gravimetric moisture content of some of the horizons of these soils (Table 1) was determined by the gravimetric method (Embrapa, 1997). Data from penetrometer impact on soil dynamic resistance was transformed with the equation proposed by Stolf (1991): R $\left(\mathrm{kgf} \mathrm{cm}{ }^{-2}\right)=5.6+6.89 \mathrm{~N}^{-1} \mathrm{dm}^{-1}$ impact). The results obtained in $\mathrm{kgf} \mathrm{cm}^{-2}$ were converted to MPa by multiplying by the constant 0.0981 .

Still in the field, the saturated hydraulic conductivity was determined in the same soil using the Guelph permeameter (model 2800), with constant hydraulic heads (H) of 5 to $10 \mathrm{~cm}$. Two measurements were taken per layer (holes in the soil to a depth of $20 \mathrm{~cm}$ and $40 \mathrm{~cm}$ ), on sites representative of each soil class, with the same treatment given to the selection of sites for resistance to penetration. Ks were calculated by the equation proposed by Soil Moisture Corp. (1991):

$$
\mathrm{Ks}=\left[(0.0041)(\mathrm{X})\left(\mathrm{R}_{2}\right)-(0.0054)(\mathrm{X})\left(\mathrm{R}_{1}\right)\right]
$$

where:

$\mathrm{Ks}=$ saturated hydraulic conductivity in $\mathrm{cm} / \mathrm{s}$;

R1, R2 - stabilized infiltration rates corresponding to H1 and $\mathrm{H} 2$ respectively, in $\mathrm{cm} / \mathrm{s}$;

$\mathrm{X}$ - Constant corresponding to the water tank, in $\mathrm{cm}^{2}$. The constant used was $\mathrm{X}=35.46 \mathrm{~cm}^{2}$.

0.0041 and 0.0054 - dimensionless values

Table 1 - Gravimetric moisture of soil samples from profiles of Oxisols and Ultisols collected prior to the penetration resistance test

\begin{tabular}{lcc}
\hline Horizon & Depth $(\mathbf{c m})$ & Moisture $\left(\mathbf{m}^{\mathbf{3}} \mathbf{~}^{-3}\right)$ \\
\hline \multicolumn{3}{c}{ PVd - Typic Paleudults } \\
\hline Ap2 & $2-12$ & 0,186 \\
Bt2 & $42-80$ & 0,350 \\
\hline \multicolumn{3}{c}{ LVd - Typic Hapludox } \\
\hline Ap1 & $0-12$ & 0,279 \\
Bw1 & $27-62$ & 0,203 \\
\hline \multicolumn{3}{|}{ PAd - Typic Hapludults } \\
\hline A1 & $0-13$ & 0,246 \\
Bw1 & $38-60$ & 0,244 \\
\hline \multicolumn{3}{c}{ LAd - Typic Hapludox } \\
\hline A1 & $0-25$ & 0,246 \\
Bw1 & $52-89$ & 0,244 \\
\hline
\end{tabular}


The mineralogical characterization was performed in diagnostic horizons of the soil profiles to aid the interpretation of morphological data and results of physical analysis. X-ray diffraction was used for the identification of silicate clay minerals (Whittig \& Allardice, 1986). Initially, it was carried out the oxidation of organic matter in the soil samples (Anderson, 1963) and the separation of the clay fraction (Embrapa, 1997), followed by iron oxides removal from these particles using dithionite-citrate (Coffin, 1963). Oriented samples, deferrated and $\mathrm{K}$ solvated were mounted on glass slides for identification of clay minerals from the diffractograms, according to Chen (1977).

\section{RESULTS AND DISCUSSION}

\section{Morphology}

LVd, PAd and LAd are the deepest profiles among those representatives of the studied area (Table 2). Besides the depth, other morphological characteristics such as grain size and porosity, great potential for infiltration and water storage were recorded for the profile LVd. However, this class of soil is of little extent in the area.

Despite the depth, the PAd has a cohesive layer, common to tableland soils, which restrains water infiltration. In addition, the occurrence of PAd near the river mouth, make these soils less interfering with the production of water, compared to soils from the headwaters of the watersheds. LAd is the deepest and most frequent (Figure 1), mostly in headwater areas, making them relevant to the water storage and groundwater recharge.

The profiles RLi, PVd and CXbd, commonly found in the Oratório Creek basin, are prone to increase runoff, because of their smaller effective depths. On the other hand, in the Limão Creek basin, the lowlands in suspended valleys of flat floors with predominance of Endoaquents (GXbd) can function as temporary water reservoirs, slowing floods downstream. However, the artificial drainage used in the field tends to reduce this effect.

Soils with granular structure were RLi, LVd and CXbd. The profiles PVd, RYbd and LAd had subangular blocky structure, and the LAd breaks into small granular structure. Massive structures were found in GXbd and PAd, the latter crumbling in subangular blocks.

The massive structure, such as the profiles RYbd and GXbd, is linked to the kaolinitic mineralogy, and also the retardation of the wetting and drying cycles in moisture preservation medium (Resende, 1985; Naime, 1988; Campos, 1999). In these soils, the face-to-face kaolinite settling restricts permeability.

The gibbsitic mineralogy of profiles such as Typic Hapludox ( $\mathrm{LVd}$ ) is responsible for the development of grain structure and its greater permeability (Ferreira et al., 1999), although, Resende (1985) points out that one must consider the contribution of iron oxides in the genesis of the structure. In this study, all soil classes had gibbsite in their constitution, however, peaks gibbsite of higher intensities were observed in the X-ray diffraction patterns of LVd, LAd and PAd (Figure 1).

When assessing dry consistency, two very contrasting conditions were noted: Typic Hapludox (LVd) with soft consistency and Typic Endoaquents (GXbd) with hard consistency. The other profiles had intermediate consistency. Kaolinite sedimentation in water environment, during the formation of these soils, facilitate the face-to-face kaolinite settling (Resende, 1985; Naime, 1988), which is reflected in the higher hardness when these soils are dry. Even when assessing the consistency of the soils when they were wet, Typic Endoaquents had greater resistance to break, showing little friability.

The highest degrees of stickiness and plasticity were associated with horizons with more clay and less organic matter. In general, the profiles RLi, CXbd, and RYbd and GXbd were slightly sticky and slightly plastic and PVd, LVD, PAd and LAd were sticky and plastic.

\section{Physical Characteristics}

The low silt fraction (Table 3) showed the advanced weathering stage of the soils. Exception occurred for the Lithic Udifolists (RLi), which had a high silt/clay ratio. The profiles RYbd and GXbd, despite the unfavorable reducing environment and the intense weathering, had intermediate silt/clay ratio, which is related to sedimentation of preweathered material from higher elevations.

Table 3 shows that most soils are between medium and clay texture. However, all tended to be sandier in the surface horizons. In PVd, PAd and, to a lesser extent, in LAd, this fact probably results from the process of argilluviation. A 2-inch thick sand layer, corresponding to the Ap1 horizon of PVd, revealed a process of differential erosion, probably as a result of the high slope and the difficult infiltration of water in the Bt horizon. This process is also clearly seen in RLi, which developed on steep slopes and directly on the rock. Differential loss of clay favored by rugged relief was suggested by Nunes et al. (2001) to explain the different texture gradients between Ultisols and Alfisols of the Viçosa Plateau (MG).

Most profiles showed a high degree of flocculation, mainly Oxisols (Table 3). But, for the surface horizons of Ultisols these values were slightly lower, which increases susceptibility to erosion and contributes to textural differentiation.

The sand layers, interspersed with layers of finer texture in the profile RYbd, indicate oscillations of periods of heavy rainfall. These layers of coarser texture may be related to the high percentage of areas with slope of strong 
Table 2 - Summary of the morphological description of the different soil profiles in the Guarapari River Basin

\begin{tabular}{|c|c|c|c|c|c|c|}
\hline Horizon & Depth (m) & Color & Texture & Structure & Consistency & Transition \\
\hline \multicolumn{7}{|c|}{ RLi - Lithic Udifolists } \\
\hline $\mathrm{H}$ & $0-0.10$ & 7.5 YR $2.5 / 2$ & $\mathrm{fa}$ & $1 \mathrm{p} \mathrm{gr}$ & $\mathrm{d} 2 \mathrm{f} 4 \mathrm{p} 1 \mathrm{~g} 1$ & \\
\hline \multicolumn{7}{|c|}{ PVd - Typic Paleudults } \\
\hline Ap1 & $0-0.02$ & 10 YR 4/4 & af & pgs & d1 f1 p1 g1 & Tpc \\
\hline Ap 2 & $0.02-0.12$ & $7.5 \mathrm{YR} 4 / 4$ & fra & $1 \mathrm{p} \mathrm{gr}$ & $\mathrm{d} 2 \mathrm{f} 1 \mathrm{p} 3 \mathrm{~g} 3$ & $\mathrm{Tpc}$ \\
\hline E & $0.12-0.24$ & 5 YR 5/8 & fra & $1 \mathrm{~m} \mathrm{bs}$ & $\mathrm{d} 3 \mathrm{f} 3 \mathrm{p} 3 \mathrm{~g} 3$ & $\mathrm{Tpc}$ \\
\hline BA & $0.24-0.42$ & $2.5 \mathrm{YR} 4 / 8$ & ra & $2 \mathrm{~m} \mathrm{bs}$ & $\mathrm{d} 3 \mathrm{f} 4 \mathrm{p} 3 \mathrm{~g} 3$ & Tpg \\
\hline Bt1 & $0.42-0.80$ & $2.5 \mathrm{YR} 5 / 8$ & $\mathrm{r}$ & $2 \mathrm{~m} \mathrm{bs}$ & $\mathrm{d} 4 \mathrm{f} 4 \mathrm{p} 3 \mathrm{~g} 3$ & Tpg \\
\hline Bt2 & $0.80-1.22$ & $2.5 \mathrm{YR} 5 / 8$ & $\mathrm{r}$ & $2 \mathrm{mbs}$ & d 3 f4 p3 g3 & Tpg \\
\hline $\mathrm{BC}$ & $1.22-1.50$ & 2.5 YR 5/8 & $\mathrm{r}$ & $2 \mathrm{mbs}$ & d 3 f4 p3 g3 & Tog \\
\hline $\mathrm{C}$ & $1.50-1.85+$ & 2.5 YR M 5 Y 5/8 & $\mathrm{fr}$ & 0 & d 3 f3 p3 g3 & \\
\hline $\mathrm{Cr}$ & $4.50-4.80+$ & V 2.5 Y 7/8 2.5 Y 8/2 10 YR 4/6 & af & 0 & $\mathrm{~d} 2 \mathrm{f} 3 \mathrm{p} 1 \mathrm{~g} 1$ & \\
\hline \multicolumn{7}{|c|}{ LVd - Typic Hapludox } \\
\hline A & $0-0.12$ & 5 YR $4 / 6$ & $\mathrm{fr}$ & $2 \mathrm{mgr}$ & d3 f3 p3 g3 & Toc \\
\hline BA & $0.12-0.27$ & $2.5 \mathrm{YR} 4 / 6$ & $\mathrm{r}$ & $2 \mathrm{pgr}$ & $\mathrm{d} 2 \mathrm{f} 3 \mathrm{p} 3 \mathrm{~g} 3$ & Tpg \\
\hline Bw1 & $0.27-0.62$ & $2.5 \mathrm{YR} 4 / 6$ & $\mathrm{ra}$ & $2 \mathrm{p} \mathrm{gr}$ & $\mathrm{d} 2 \mathrm{f} 3 \mathrm{p} 3 \mathrm{~g} 3$ & Tpd \\
\hline Bw2 & $0.62-1.25$ & $2.5 \mathrm{YR} 4 / 6$ & $\mathrm{r}$ & $2 \mathrm{p} \mathrm{gr}$ & d2 f3 p3 g3 & Tpd \\
\hline Bw3 & $1.25-1.63$ & $2.5 \mathrm{YR} 4 / 6$ & $\mathrm{r}$ & $2 \mathrm{p} \mathrm{gr}$ & $\mathrm{d} 2 \mathrm{f} 3 \mathrm{p} 3 \mathrm{~g} 3$ & Tpd \\
\hline Bw4 & $1.63-2.20+$ & 2.5 YR 4/6 & $\mathrm{r}$ & $2 \mathrm{pgr}$ & $\mathrm{d} 2 \mathrm{f} 3 \mathrm{p} 3 \mathrm{~g} 3$ & \\
\hline \multicolumn{7}{|c|}{ CXbd - Oxic Dystrudepts } \\
\hline$A p$ & $0-0.12$ & 7.5 YR 3/1 & fa & $1 \mathrm{pgr}$ & d2 2 3 p1 g2 & Tpg \\
\hline $\mathrm{AB}$ & $0.12-0.28$ & $10 \mathrm{YR} 5 / 2$ & fra & $1 \mathrm{p} \mathrm{gr}$ & d2 f3 p2 g2 & Tpg \\
\hline BA & $0.28-0.40$ & $10 \mathrm{YR} 4 / 6$ & fra & $1 \mathrm{p} \mathrm{gr}$ & d2 f3 p2 g2 & $\mathrm{Tpc}$ \\
\hline Bi1 & $0.40-0.60$ & $10 \mathrm{YR} 4 / 4$ & fra & $1 \mathrm{p} \mathrm{gr}$ & $\mathrm{d} 3 \mathrm{f} 3 \mathrm{p} 2 \mathrm{~g} 2$ & $\mathrm{Tpc}$ \\
\hline Bi2 & $0.60-0.80$ & $10 \mathrm{YR} 4 / 4$ & fra & & d 3 f3 p2 g2 & \\
\hline Bi3 & $0.80-1.10+$ & $10 \mathrm{YR} 4 / 4$ & fra & & $\mathrm{d} 3 \mathrm{f} 3 \mathrm{p} 2 \mathrm{~g} 2$ & \\
\hline \multicolumn{7}{|c|}{ RYbd - Oxyaquic Udifluventes } \\
\hline Ap 1 & $0-0.10$ & $7.5 \mathrm{YR} 4 / 4$ & af & $\mathrm{pgs}$ & $\mathrm{d} 2 \mathrm{f} 1 \mathrm{p} 1 \mathrm{~g} 1$ & Tpa \\
\hline Ap 2 & $0.10-0.18$ & $7.5 \mathrm{YR} 4 / 4$ & fra & $1 \mathrm{p} \mathrm{bs}$ & $\mathrm{d} 4 \mathrm{f} 3 \mathrm{p} 2 \mathrm{~g} 2$ & Tpa \\
\hline $\mathrm{C} 1$ & $0.18-0.29$ & 7.5 YR 4/4 Mppdis 10R 3/6 & $\mathrm{fr}$ & $1 \mathrm{p} \mathrm{bs}$ & $\mathrm{d} 3 \mathrm{f} 4 \mathrm{p} 2 \mathrm{~g} 2$ & $\mathrm{Tpc}$ \\
\hline $\mathrm{C} 2$ & $0.29-0.40$ & 7.5 YR 4/6 Mppdis 10R 3/6 & $\mathrm{fa}$ & $1 \mathrm{p} \mathrm{bs}$ & $\mathrm{d} 2 \mathrm{f} 4 \mathrm{p} 2 \mathrm{~g} 2$ & $\mathrm{Tpc}$ \\
\hline $\mathrm{C} 3$ & $0.40-0.46$ & $10 \mathrm{YR} 4 / 4$ Mppdis $10 \mathrm{R} 3 / 6$ & $\mathrm{a}$ & p gs & $\mathrm{d} 2 \mathrm{f} 4 \mathrm{p} 1 \mathrm{~g} 1$ & Tpa \\
\hline $\mathrm{Cg}$ & $0.46-0.69+$ & $2.5 \mathrm{Y} 4 / 2 \mathrm{Mcmdis} 10 \mathrm{R} 3 / 6$ & fra & 0 & $\mathrm{~d} 4 \mathrm{f} 4 \mathrm{p} 2 \mathrm{~g} 2$ & \\
\hline \multicolumn{7}{|c|}{ PAd - Typic Hapludults } \\
\hline Ap 1 & $0-0.13$ & $10 \mathrm{YR} 4 / 4$ & fra & $2 \mathrm{pgr}$ & d3 f3 p2 g2 & Tpd \\
\hline Ap 2 & $0.13-0.25$ & $10 \mathrm{YR} 4 / 4$ & fra & $2 \mathrm{mgr}$ & $\mathrm{d} 3 \mathrm{f} 3 \mathrm{p} 2 \mathrm{~g} 2$ & Tpd \\
\hline $\mathrm{AB}$ & $0.25-0.38$ & $10 \mathrm{YR} 4 / 4$ & fra & $2 \mathrm{mgr}$ & $\mathrm{d} 3 \mathrm{f} 3 \mathrm{p} 2 \mathrm{~g} 3$ & Toc \\
\hline $\mathrm{Bt} 1$ & $0.38-0.60$ & 7.5 YR 5/8 & $\mathrm{r}$ & 0 & d4 f3 p3 g3 & Tpd \\
\hline $\mathrm{Bt} 2$ & $0.60-0.87$ & $7.5 \mathrm{YR} 5 / 8$ & $\mathrm{r}$ & 0 & d4 f3 p3 g3 & Tpd \\
\hline $\mathrm{Bt} 3$ & $0.87-1.40$ & $7.5 \mathrm{YR} 5 / 8$ & $\mathrm{r}$ & 0 & d 3 f3 p3 g3 & Tpd \\
\hline $\mathrm{Bt} 4$ & $1.40-2.10+$ & $7.5 \mathrm{YR} 5 / 8$ & $\mathrm{r}$ & 0 & $\mathrm{~d} 3 \mathrm{f} 3 \mathrm{p} 3 \mathrm{~g} 3$ & \\
\hline \multicolumn{7}{|c|}{ GXbd - Typic Endoaquents } \\
\hline $\mathrm{Ap}$ & $0-0.17$ & 10YR 3/2 Mppdis 10 R 4/6 & $\mathrm{r}$ & $1 \mathrm{pgr}$ & $\mathrm{d} 4 \mathrm{f} 4 \mathrm{p} 1 \mathrm{~g} 1$ & $\operatorname{Tog}$ \\
\hline Cg1 & $0.17-0.37$ & 10YR 3/2 Mcpdis $10 \mathrm{R}$ 4/6 & $\mathrm{R}$ & 0 & d4 f5 p2 g2 & Toc \\
\hline $\mathrm{Cg} 2$ & $0.37-0.65+$ & $2.54 / 4$ & fra & 0 & $\mathrm{~d} 4 \mathrm{f} 5 \mathrm{p} 2 \mathrm{~g} 2$ & \\
\hline \multicolumn{7}{|c|}{ LAd - Typic Hapludox } \\
\hline Ap & $0-0.25$ & $10 \mathrm{YR} 5 / 6$ & fra & $2 \mathrm{mgr}$ & d3 f3 p2 g2 & Tpc \\
\hline BA & $0.25-0.52$ & 10 YR $6.5 / 8$ & fra & $1 \mathrm{p} \mathrm{bs}$ & d 3 f4 p3 g2 & Tog \\
\hline Bw1 & $0.52-0.89$ & 10 YR $6.5 / 8$ & fra & $1 \mathrm{~m} \mathrm{bs}$ & $\mathrm{d} 3 \mathrm{f} 4 \mathrm{p} 3 \mathrm{~g} 2$ & Tod \\
\hline Bw2 & $0.89-1.22$ & 10 YR 6/8 & $\mathrm{ra}$ & $1 \mathrm{~m} \mathrm{bs}$ & $\mathrm{d} 2 \mathrm{f} 4 \mathrm{p} 3 \mathrm{~g} 2$ & Tod \\
\hline Bw3 & $1.22-1.73$ & 10 YR 6/8 & $\mathrm{ra}$ & $1 \mathrm{~m} \mathrm{bs}$ & $\mathrm{d} 3 \mathrm{f} 4 \mathrm{p} 3 \mathrm{~g} 2$ & Tog \\
\hline Bw4 & $1.73-2.20+$ & $10 \mathrm{YR} 6 / 8$ & $\mathrm{ra}$ & $1 \mathrm{~m} \mathrm{bs}$ & $\mathrm{d} 3 \mathrm{f} 4 \mathrm{p} 3 \mathrm{~g} 2$ & \\
\hline
\end{tabular}

Color: $\mathrm{M}=$ mottled pattern; Mcmdis = common medium distinctive mottled; Mcpdis = common small distinctive mottled; Mppdis = slightly small distinctive mottled; $\mathrm{Mpp}=$ slightly small mottled. Texture: $\mathrm{R}=$ very clay; $\mathrm{r}=$ clay and clayey; ra = clay-sandy; $\mathrm{f}=$ frank; fa = frank sandy; Fra = frank clay sandy; Fr = frank clay; fa = frank sandy; af = frank sand. Structure: $1=$ weak; $2=$ moderate; $3=$ strong; $\mathrm{mp}=$ very small; $\mathrm{p}=$ small; $\mathrm{m}=$ medium; $\mathrm{g}=$ large bs = subangular blocky; gs = simple granular; gr = granular; $0=$ solid Consistency: $\mathrm{d} 1$ = loose; $\mathrm{d} 2=$ soft; $\mathrm{d} 3=$ slightly hard; $\mathrm{d} 4=$ hard; $\mathrm{d} 5=$ very hard; $\mathrm{f} 1=$ loose; $\mathrm{f} 2=$ very friable; $\mathrm{f} 3=$ friable; $\mathrm{f} 4=$ firm; $\mathrm{f} 5=$ very firm; $\mathrm{p} 1=$ not plastic; $\mathrm{p} 2$ = slightly plastic; $\mathrm{p} 3$ = plastic; $\mathrm{g} 1=$ non sticky; $\mathrm{g} 2$ = slightly sticky; $\mathrm{g} 3=$ sticky. Transition: Tpa = flat and abrupt transition; Toc = clear and undulating transition; Tog = gradual undulating transition; Tpc = flat and clear transition; Tpd = flat and diffuse transition; Tpg = flat and gradual transition; Tod = diffuse undulating transition. 
undulation to steep hills, associated with shallow soils of the Oratorio Creek basin, which provides surface runoff with higher energy to carry sediments.

Soil bulk density ranged from 0.76 to $1.65 \mathrm{~kg} \mathrm{dm}^{-3}$ (Table 3). The profiles CXbd, PAd, GXbd and LAd tended to have higher density in the subsurface horizons, while PVd, LVd and RYbd, in the surface horizons. The higher density in these three soil horizons are probably related to the differences in the intensity of use in relation to the others.

High soil density was observed for the Bt1 horizon of PAd, because of the genesis of compacted layers, common in soils of the Coastal Tablelands, which has not yet been fully clarified (Panos, 1976; UFV, 1984; Anjos, 1985; Fonseca, 1986; and Meirelles \& Ribeiro, 1995).

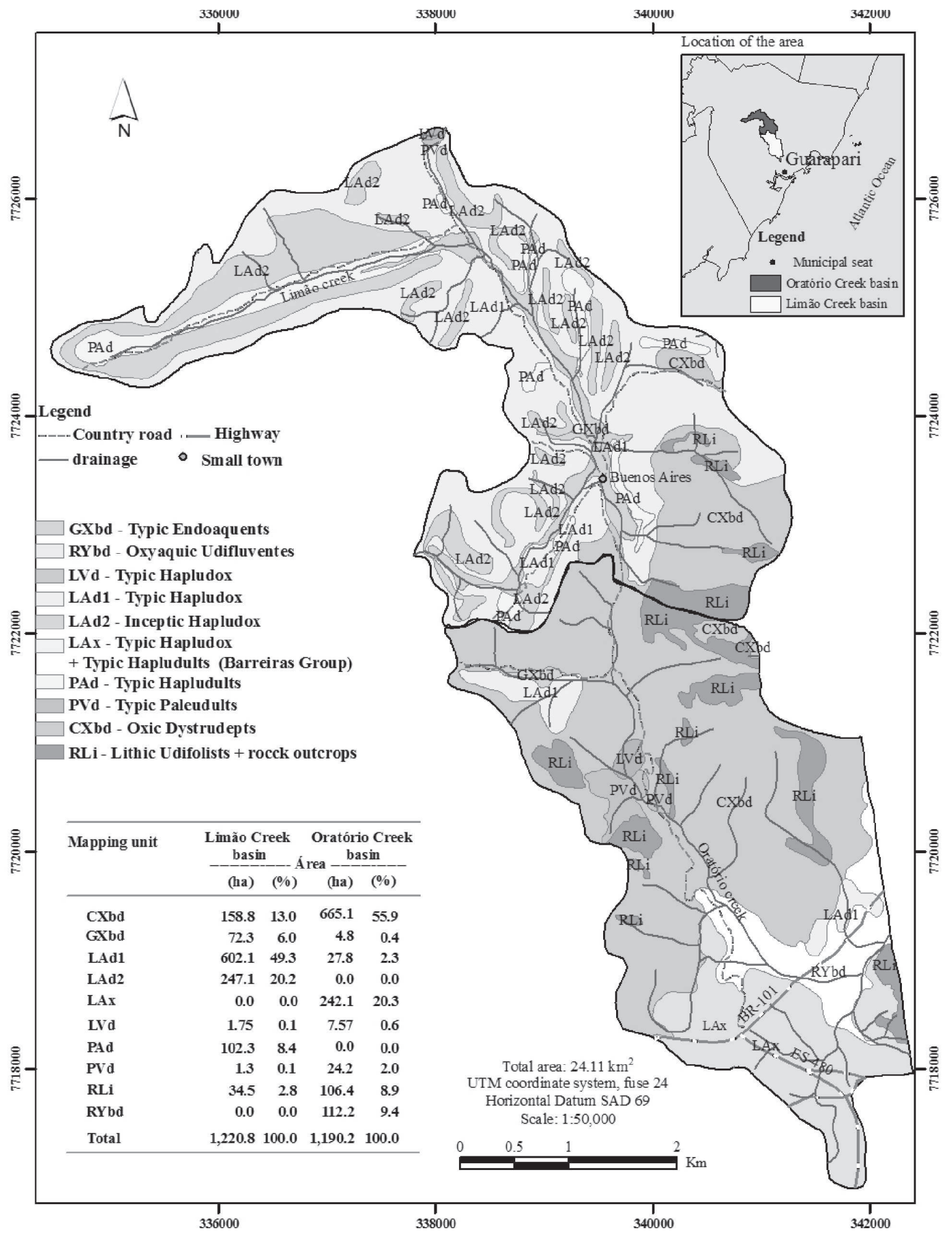

Figure 1 - Map of the soils in the watersheds of Limão and Oratorio Creeks. 
The granular structure is probably responsible for the lower density throughout the profile of the Typic Hapludox (LVd). The granular structure has a lower tendency to compactation, compared with the blocky structure, owing to the predominance of face-to-face kaolinite settling.

The density in soil surface horizons showed no effect of the use of Brachiaria spp, even for Typic Endoaquents, in which soil samples were collected from mini-trenches opened in the pasture. Although this fact has not been observed in the present study, many studies show the effect of cattle trampling on the soil surface layers (Bertol et al. 2000; Chancellor et al. 1962, Costa et al. 2000; Gradwell, 1960 ; Vzzotto et al., 2000).

There was variation of porosity with depth within each profile and between different profiles (Table 3). Comparing deep and well-drained soils (LVd and LAd), we found that

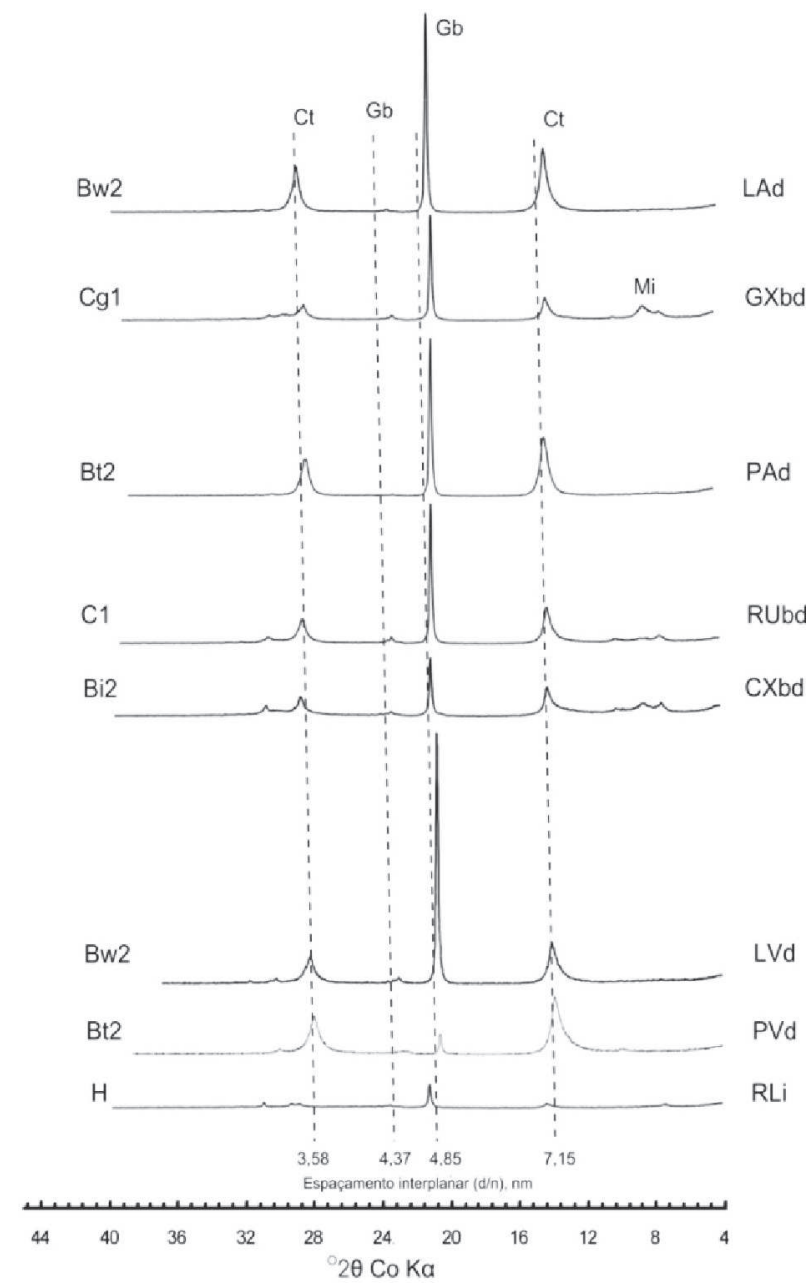

Figure 2 - X-ray diffraction patterns of clay fraction (deferrated, $\mathrm{K}$ solvated and mounted on glass slides) of the profiles RLiLithic Udifolists (H), PVd - Typic Paleudults (Bt2), LVd - Typic Hapludox (Bw2), CXbd - Oxic Dystrudepts (Bi2), RYbd Oxyaquic Udifluventes (C1), PAd - Typic Hapludults (Bt2) GXbd - Typic Endoaquents (Cg1) and LAd - Typic Hapludox (Bw2). Ct - kaolinite, Gb - gibbsite, MI - mica. the $\mathrm{Bw} 1$ horizon, more gibbsitic ( $\mathrm{LVd})$ and with granular structure, was more porous $\left(0.56 \mathrm{~m}^{3} \mathrm{~m}^{-3}\right)$ than the Bw1 horizon of LAd $\left(0.41 \mathrm{~m}^{3} \mathrm{~m}^{-3}\right)$, which had subangular blocky structure that breaks into granular. The Bt1 horizon of PAd, with massive structure that breaks into subangular blocks, had porosity similar to Bw1 of LAd.

\section{Water Retention}

Values of water retention, obtained at the potentials $0.01 \mathrm{MPa}$ and 1.5 MPa for the deepest soils of the watersheds (PVd, LVd, PAd and LAd) were different for surface $(\mathrm{A})$ and subsurface $(\mathrm{Bw}$ and $\mathrm{Bt}$ ) horizons (Figure 3).

Considering the Oxisols and Ultisols, for the A horizon, the profile that retained more water was $\mathrm{LVd}$. The higher clay $\left(380 \mathrm{~g} \mathrm{~kg}^{-1}\right)$ and organic matter (3.79 dag kg-1) contents in the A horizon of this profile, as compared with LAd, PAd and PVd (Table 3), were probably the causes of the greater volume of water retained. Because these soils showed no significant differences in clay activity, it is possible that different levels of clay between profiles and between the horizons of each profile are more important in the differentiation of water retention capacity (Figure 3 ).

In the subsurface horizons ( $\mathrm{Bw}$ and $\mathrm{Bt}$ ), with lower influence of organic matter, the relationship between the higher clay content and the greater capacity to retain water becomes more evident, probably reflecting the activity of the predominant clay (kaolinite) and the less developed structure in relation to LVd and LAd, which did not have the same behavior. The explanation for lower moisture retention for these last two profiles seems to be related to the typical mineralogy of Oxisols, with greater contribution of iron oxides and aluminum, which, according to Resende (1985), result in structures tending to granular, as in LAd

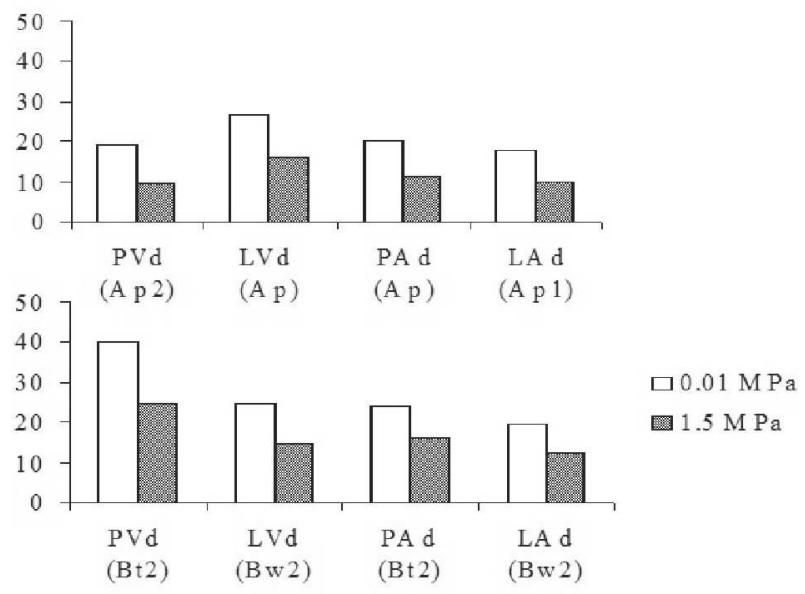

Figure 3 - Water retention in soil between the potentials 0.01 $\mathrm{MPa}$ and 1.5 MPa for Ap2 and $\mathrm{Bt} 2$ horizons of the Typic Paleudults (PVd); Ap and Bw2 of the Typic Hapludox (LVd); Ap and BT2 the Typic Hapludults (PAd); Ap1 and Bw2 of the Typic Hapludox (LAd).

Rev. Ceres, Viçosa, v. 58, n.4, p. 493-503, jul/ago, 2011 
Table 3 - Grain size, water dispersible clay (WDC), degree of flocculation (GF), silt/clay ratio, bulk (Ds) and particle density (Dp), porosity (Poros.), moisture equivalent (U.S.) and organic carbon (C)

\begin{tabular}{|c|c|c|c|c|c|c|c|c|c|c|c|c|c|}
\hline \multirow[t]{2}{*}{ Horiz. } & \multirow[t]{2}{*}{ Depth (m) } & \multirow[t]{2}{*}{$\begin{array}{c}\text { Sand } \\
\text { Coarse } \\
\end{array}$} & $\begin{array}{l}\text { Sand } \\
\text { Fine }\end{array}$ & Silt & Clay & WDC & \multirow{2}{*}{$\begin{array}{c}\text { GF } \\
\%\end{array}$} & \multirow{2}{*}{$\begin{array}{l}\text { Silt/ } \\
\text { Clay }\end{array}$} & Ds & \multirow[t]{2}{*}{ Dp } & \multirow{2}{*}{$\frac{\text { Poros. }}{\mathbf{m}^{3} \mathbf{m}^{-3}}$} & \multirow{2}{*}{$\frac{\text { E. U. }}{\mathrm{kg} \mathrm{kg}^{-1}}$} & \multirow{2}{*}{$\frac{\mathrm{C}}{\text { dag } \mathrm{kg}^{-1}}$} \\
\hline & & & & \multicolumn{2}{|c|}{$\mathrm{g} \mathrm{kg}^{-1}$} & & & & $\mathrm{~kg} \mathrm{dm}^{-3}$ & & & & \\
\hline \multicolumn{14}{|c|}{ RLi - Lithic Udifolists } \\
\hline $\mathrm{H}$ & $0.0-0.10$ & 640 & 70 & 160 & 130 & 20 & 85 & 1.23 & - & - & - & - & 12.99 \\
\hline \multicolumn{14}{|c|}{ PVd - Typic Paleudults } \\
\hline$\overline{\mathrm{Ap} 1}$ & $0.0-0.02$ & 790 & 40 & 60 & 110 & 30 & 73 & 0.55 & - & - & - & - & 3.38 \\
\hline Ap 2 & $0.02-0.12$ & 600 & 70 & 100 & 230 & 50 & 78 & 0.43 & 1.41 & 2.59 & 0.45 & 0.15 & 2.57 \\
\hline $\mathrm{E}$ & $0.12-0.24$ & 520 & 80 & 90 & 310 & 100 & 68 & 0.29 & - & - & - & - & 2.17 \\
\hline BA & $0.24-0.42$ & 510 & 50 & 70 & 370 & 90 & 76 & 0.19 & - & - & - & - & 1.90 \\
\hline Bt1 & $0.42-0.80$ & 290 & 30 & 90 & 590 & 0 & 100 & 0.15 & 1.32 & 2.63 & 0.50 & 0.23 & 1.76 \\
\hline Bt2 & $0.80-1.22$ & 260 & 40 & 130 & 570 & 0 & 100 & 0.23 & 1.24 & 2.63 & 0.53 & 0.29 & 1.49 \\
\hline $\mathrm{BC}$ & $1.22-1.50$ & 250 & 40 & 150 & 560 & 60 & 89 & 0.27 & - & - & - & - & 1.22 \\
\hline $\mathrm{C}$ & $1.50-1.85+$ & 310 & 70 & 260 & 360 & 20 & 94 & 0.72 & - & - & - & - & 0.29 \\
\hline $\mathrm{Cr}$ & $4.50-4.80+$ & 590 & 190 & 160 & 60 & 0 & 100 & 2.67 & - & - & - & - & 0.29 \\
\hline \multicolumn{14}{|c|}{ LVd - Typic Hapludox } \\
\hline $\bar{A}$ & $0.0-0.12$ & 390 & 60 & 170 & 380 & 60 & 89 & 0.45 & 1.38 & 2.59 & 0.47 & 0.10 & 3.79 \\
\hline $\mathrm{BA}$ & $0.12-0.27$ & 360 & 60 & 120 & 460 & 110 & 76 & 0.26 & 1.31 & 2.63 & 0.50 & 0.20 & 1.76 \\
\hline Bw1 & $0.27-0.62$ & 430 & 50 & 110 & 410 & 100 & 76 & 0.27 & 1.14 & 2.59 & 0.56 & 0.18 & 1.49 \\
\hline Bw2 & $0.62-1.25$ & 330 & 60 & 120 & 490 & 70 & 86 & 0.24 & 1.24 & 2.65 & 0.53 & 0.17 & 1.36 \\
\hline Bw3 & $1.25-1.63$ & 360 & 60 & 100 & 480 & 0 & 100 & 0.21 & - & - & - & - & 1.36 \\
\hline Bw4 & $1.63-2.20+$ & 380 & 60 & 100 & 460 & 10 & 98 & 0.22 & - & - & - & - & 0.94 \\
\hline \multicolumn{14}{|c|}{ CXbd - Oxic Dystrudepts } \\
\hline$\overline{A p}$ & $0-0.12$ & 670 & 50 & 110 & 170 & 30 & 82 & 0.65 & 1.25 & 2.63 & 0.52 & 0.16 & 3.66 \\
\hline $\mathrm{AB}$ & $0.12-0.28$ & 420 & 120 & 170 & 290 & 50 & 83 & 0.59 & - & - & - & - & 2.16 \\
\hline $\mathrm{BA}$ & $0.28-0.40$ & 590 & 60 & 130 & 220 & 50 & 77 & 0.59 & - & - & - & - & 1.62 \\
\hline Bi1 & $0.40-0.60$ & 600 & 70 & 70 & 260 & 50 & 81 & 0.27 & 1.44 & 2.64 & 0.45 & 0.13 & 1.62 \\
\hline $\mathrm{Bi} 2$ & $0.60-0.80$ & 580 & 70 & 70 & 280 & 70 & 75 & 0.25 & - & - & - & - & 1.36 \\
\hline $\mathrm{Bi} 3$ & $0.80-1.10+$ & 510 & 70 & 50 & 370 & 0 & 100 & 0.14 & - & - & - & - & 1.36 \\
\hline & & & & & $\mathrm{bd}-\mathrm{Ox}$ & yaquic $\mathrm{L}$ & difluve & & & & & & \\
\hline Ap 1 & $0-0.10$ & 750 & 70 & 80 & 100 & 30 & 70 & 0.80 & 1.40 & 2.66 & 0.47 & 0.09 & 2.03 \\
\hline Ap2 & $0.10-0.18$ & 400 & 200 & 180 & 220 & 20 & 91 & 0.82 & 1.30 & 2.50 & 0.48 & 0.20 & 3.66 \\
\hline $\mathrm{C} 1$ & $0.18-0.29$ & 270 & 180 & 240 & 310 & 20 & 94 & 0.77 & - & - & - & - & 3.79 \\
\hline $\mathrm{C} 2$ & $0.29-0.40$ & 520 & 230 & 90 & 160 & 20 & 88 & 0.56 & - & - & - & - & 1.76 \\
\hline $\mathrm{C} 3$ & $0.40-0.46$ & 840 & 60 & 30 & 70 & 10 & 86 & 0.43 & - & - & - & - & 0.95 \\
\hline $\mathrm{Cg}$ & $0.46-0.69+$ & 370 & 210 & 180 & 240 & 40 & 83 & 0.75 & 0.99 & 2.50 & 0.60 & 0.25 & 2.57 \\
\hline & & & & & PAd - & ypic $\mathrm{H}$ & pludult & & & & & & \\
\hline Ap1 & $0-0.13$ & 550 & 50 & 120 & 280 & 60 & 79 & 0.43 & 1.16 & 2.63 & 0.56 & 0.17 & 3.52 \\
\hline Ap 2 & $0.13-0.25$ & 560 & 50 & 120 & 270 & 40 & 85 & 0.44 & - & - & - & - & 3.11 \\
\hline $\mathrm{AB}$ & $0.25-0.38$ & 510 & 60 & 100 & 330 & 30 & 91 & 0.30 & - & - & - & - & 2.71 \\
\hline Bt1 & $0.38-0.60$ & 340 & 70 & 120 & 470 & 0 & 100 & 0.26 & 1.55 & 2.59 & 0.40 & 0.20 & 1.90 \\
\hline $\mathrm{Bt} 2$ & $0.60-0.87$ & 340 & 60 & 80 & 520 & 50 & 90 & 0.15 & - & - & - & - & 1.36 \\
\hline Bt3 & $0.87-1.40$ & 360 & 60 & 70 & 510 & 0 & 100 & 0.14 & - & - & - & - & 1.07 \\
\hline Bt4 & $1.40-2.10+$ & 360 & 60 & 60 & 520 & 0 & 100 & 0.12 & 1.01 & 2.70 & 0.63 & 0.24 & 1.07 \\
\hline & & & & & $\mathrm{Xbd}-$ & ypic Er & loaque & & & & & & \\
\hline$A \bar{p}$ & $0-0.17$ & 220 & 130 & 290 & 360 & 10 & 97 & 0.81 & 0.76 & 2.38 & 0.68 & 0.35 & 5.19 \\
\hline $\mathrm{Cg} 1$ & $0.17-0.37$ & 330 & 150 & 170 & 350 & 50 & 86 & 0.81 & 1.11 & 2.59 & 0.57 & 0.21 & 1.45 \\
\hline $\mathrm{Cg} 2$ & $0.37-0.65+$ & 480 & 140 & 110 & 270 & 30 & 89 & 0.41 & 1.28 & 2.70 & 0.53 & 0.18 & 1.08 \\
\hline & & & & & LAd - & Typic $\mathrm{H}$ & pludox & & & & & & \\
\hline Ap & $0-0.25$ & 580 & 70 & 120 & 230 & 30 & 87 & 0.52 & 1.35 & 2.59 & 0.48 & 0.12 & 1.36 \\
\hline BA & $0.25-0.52$ & 480 & 70 & 110 & 340 & 70 & 79 & 0.32 & - & - & - & - & 1.36 \\
\hline Bw1 & $0.52-0.89$ & 460 & 80 & 250 & 210 & 10 & 95 & 1.19 & 1.60 & 2.70 & 0.41 & 0.17 & 0.81 \\
\hline Bw2 & $0.89-1.22$ & 510 & 60 & 80 & 350 & 60 & 83 & 0.23 & - & - & - & - & 0.68 \\
\hline Bw3 & $1.22-1.73$ & 500 & 70 & 80 & 350 & 0 & 100 & 0.21 & 1.65 & 2.70 & 0.39 & 0.16 & 0.41 \\
\hline Bw4 & $1.73-2.20+$ & 430 & 80 & 130 & 360 & 0 & 100 & 0.36 & - & - & - & - & 0.14 \\
\hline
\end{tabular}


(subangular blocks break into granular) and in LVd and CXbd (granular), which tend to have higher proportion of macropores.

\section{Resistance to penetration}

Differences in penetration resistance were found along the depth evaluated and between soils, probably because of the effect of land use and characteristics of the horizons in each class.

The Typic Paleudults (PVd) under banana intercropped with coffee had the highest penetration resistance in the subsurface layers (B) of LVd, PAd and LAd, especially in depths greater than $35 \mathrm{~cm}$, corresponding to BA and Bt's horizons (Figure 4). This greater resistance in $\mathrm{PVd}$ occurred in the $\mathrm{Bt} 1$ horizon, which usually tends to have higher bulk density, because of the process of argilluviation (kaolinite, mostly) and, consequently, lower hydraulic conductivities.

In the Typic Hapludults (PAd), under pasture, penetration resistance was highest when measured in the cattle trails, owing to the higher soil density caused by animal trampling. Lower saturated hydraulic conductivities are generally observed in compacted soils, which provide greater surface runoff under heavy rain (Alves \& Souza, 2003; Gent Jr. et al., 1984). Between the cattle trails, with less intensive cattle trampling, soil resistance was not as high. In the two conditions (between trails and trail), at greater depths of PAd, the resistances were similar. However, according to Tormena \& Roloff (1996), penetration resistance higher than $2.0 \mathrm{MPa}$ is already considered to be an impediment for root growth.

There was a trend towards increased resistance to penetration in the surface layers of LAd, comparing the soil under pasture with the soil under secondary forest. At all depths evaluated in this profile, the soil resistance tended to be lower under forest, favoring water infiltration.

At greater depths, or rather, above $0.50 \mathrm{~m}$, there was less effect of land use and soil class characteristics became more evident. More porous soils, with lower density at this depth (LVd and PAd) offered less resistance than the Typic Paleudults (PVd) and Typic Hapludox (LAd).

\section{Hydraulic conductivity}

Saturated hydraulic conductivity (Table 4) showed large variability between replicates, especially for the profiles LVd, PAd and LAd, at both depths studied. These widely varying results may be related to the heterogeneity of soil mass regarding macropores formed by biological activity, especially in pastures, because of many fractures left by the roots.

Higher hydraulic conductivities were recorded at 0.20 $m$ depth in the four profiles examined. This fact may be associated with a higher content of organic matter in surface horizons. The additional effect of the lower clay at this depth for the profile PVd seems to explain the large hydraulic conductivity.

The drastic reduction in hydraulic conductivity at a depth of $0.40 \mathrm{~m}$ for the Typic Paleudults (PVd) is associated with its high textural gradient. Thus, the high clay content, mainly of kaolinite, seems to severely prevent water infiltration and, hence, facilitate erosion.

Based on the mineralogical characteristics, granular structure and lower densities of LVd, it was expected a higher hydraulic conductivity in the B horizon of this soil, as compared with the profiles PAd and LAd. However, this was not found. The highest values of hydraulic conductivity for the profiles PAd and LAd at $0.40 \mathrm{~m}$ depth may be associated with biological channels formed in

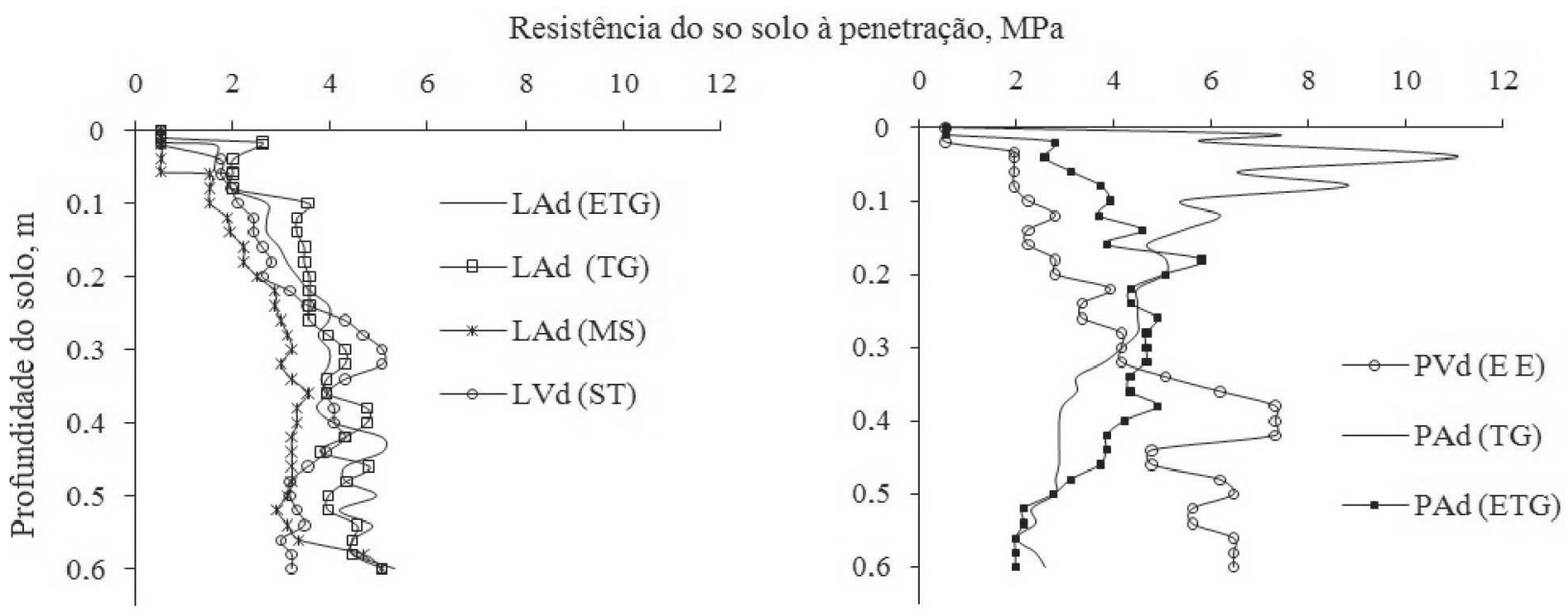

Figure 4 - Resistance to penetrometer of soils under different land uses: PVd (Typic Paleudults under banana-coffee intercropping; LVd (Typic Hapludox under pasture - without apparent cattle trails); LAd - Typic Hapludox under pasture and forest - TG = in cattle trail; ETG = between cattle trails, MS - under secondary forest and; PAd (Typic Hapludults under pasture - TG = in cattle trail; ETG $=$ between cattle trails). 
Table 4 - Saturated hydraulic conductivity of Ultisols and Oxisols of Guarapari River

\begin{tabular}{|c|c|c|c|c|c|c|}
\hline \multirow{2}{*}{ Soil } & Depth & $\mathbf{R 1}$ & $\mathbf{R 2}$ & $\overline{\mathbf{X}}$ & $\mathbf{s}$ & CV \\
\hline & $\mathrm{cm}$ & \multicolumn{4}{|c|}{$\mathbf{c m ~ h}^{-1}$} & $\%$ \\
\hline \multirow{2}{*}{ PVd } & 20 & 4.79 & 5.68 & 5.23 & 0.63 & 12.03 \\
\hline & 40 & 0.20 & 0.20 & 0.20 & 0.00 & 0.00 \\
\hline \multirow{2}{*}{ LVd } & 20 & 1.78 & 0.49 & 1.13 & 0.91 & 80.72 \\
\hline & 40 & 0.31 & 0.49 & 0.41 & 0.13 & 31.04 \\
\hline \multirow{2}{*}{ PAd } & 20 & 0.88 & 1.96 & 1.42 & 0.76 & 53.78 \\
\hline & 40 & 0.81 & 0.41 & 0.61 & 0.28 & 46.37 \\
\hline \multirow{2}{*}{ LAd } & 20 & 2.56 & 5.09 & 3.82 & 1.79 & 46.83 \\
\hline & 40 & 1.09 & 1.05 & 1.07 & 0.03 & 2.64 \\
\hline
\end{tabular}

PVd = Typic Paleudults; LVd = Typic Hapludox; PAd = Typic Hapludults Acrisol; LAd = Typic Hapludox; R1 and R2 - repetitions; X - mean; $\mathrm{s}$ - Standard deviation; CV - coefficient of variation.

these soils, coinciding with the locations where data were collected. During the descriptions of the profiles in the field, termite channels were observed over the profiles. This biological factor may help explain the higher conductivity of the profiles PAd and LAd. It is likely, in this case, that the biological activity overlaps the characteristics of the soil itself, such as structure, mineralogy and texture.

\section{CONCLUSIONS}

The Endoaquents in suspended valleys in the area of the Limão Creek can act as temporary water reservoirs, slowing floods downstream. However, artificial drainage tends to reduce this effect.

Differential erosion was confirmed by an abrupt textural gradient on the surface of the Typic Paleudults, due to the low degree of clay flocculation, slope of the terrain, high penetration resistance and low hydraulic conductivity of the Bt horizon. This horizon has high moisture retention, requiring the adoption of management practices aimed at increasing water infiltration.

Under pasture, especially on cattle trails where the trampling is more intense, there was high resistance to penetration in the surface layers.

Typic Hapludox (LAd), being most frequent in headwater areas and deep, with morphological and physical characteristics resulting in good hydraulic conductivity, have the greatest potential for the "water production " in the watersheds.

\section{REFERENCES}

Anderson JV (1963) An improved pretreatment for mineralogical analysis of samples containing organic matter. Clays and Clay Minerals, 10:380-388.

Anjos LHC (1985) Caracterização, gênese, classificação e aptidão agrícola de uma sequiência de solos do terciário na região de Campos, RJ. Dissertação de Mestrado. Universidade Federal Rural do Rio de Janeiro, Itaguaí, 194p.
Bertol I Almeida JA Almeida EX \& Kurtz C (2000) Propriedades físicas do solo relacionadas a diferentes níveis de oferta de forragem de capim-elefante-anão cv. Mott. Pesquisa Agropecuária Brasileira, 35:1047-1054.

Brasil Ministério das Minas e Energia (1983). Projeto RADAMBRASIL. Folhas SF 23/24 Rio de Janeiro/Vitória: geologia, geomorfologia, pedologia, vegetação e uso potencial da terra. Rio de Janeiro: MME/SG/Projeto RADAM BRASIL, 775p.

Campos CEB (1999) Indicadores de campo para solos hidromórficos do Planalto de Viçosa, Minas Gerais. Dissertação de Mestrado. Universidade Federal de Viçosa, Viçosa, 123p.

Chancellor WJ Schmidt RH \& Soehne W (1962) Laboratory measurement of soil compaction and plastic flow. Transactions of the American Society of Agricultural Engineers, 5:235-239.

Chen P Y (1977) Table of key lines in X-ray powder diffraction patterns of mineral in clays and associated rocks. Indiana: Bloomington, 65p. (Department of Natural Resources Geological Survey Occasional Paper 21).

Coffin DE (1963) A method for the determination of free iron in soils and clays. Canadian Journal of Soil Science, 43:7-17.

Costa OV Costa LM Fontes LEF Araujo QR Ker JC \& Nacif PGS (2000) Cobertura do solo e degradação de pastagens em área de domínio de Chernossolos no sul da Bahia. Revista Brasileira de Ciência do Solo, 24:843-856.

Costa LM Fernandes Filho EI \& Olszevisk N (2001) O solo e água. Ação Ambiental, 20:17-19.

Cunha AM, Lani JL, Amaral EF, Rezende SB \& Ribeiro LS (2006) Mosaico digital de aerofotos não-convencionais na avaliação de recursos naturais - Estudo de caso. Revista Brasileira de Engenharia Agrícola e Ambiental, 10:182-187.

Empresa Brasileira de Pesquisa Agropecuária - Embrapa (1997) Centro Nacional de Pesquisa de Solos. Manual de métodos de análise de solo. 2 ed. Brasília: Embrapa - SPI. 212p.

Empresa Brasileira de Pesquisa Agropecuária - Embrapa (1978) Serviço Nacional de Levantamento e Conservação do Solo. Levantamento de reconhecimento dos solos do Estado do Espírito Santo. Rio de Janeiro. 461p. (Boletim Técnico)

Empresa Brasileira de Pesquisa Agropecuária - Embrapa (2006) Centro Nacional de Pesquisa de Solos. Sistema Brasileiro de Classificação de Solos. 2 ed. Rio de Jeneiro: Embrapa Solos. 306 p.

Ferreira MM Fernandes B \& Curi N (1999) Mineralogia da fração argila e estrutura de Latossolos da região sudeste do Brasil. Revista Brasileira de Ciência do Solo, 23:507-514. 
Fonseca OOM (1986) Caracterização e classificação de solos latossólicos e podzólicos desenvolvidos nos sedimentos de terciário no litoral brasileiro. Dissertação de Mestrado. Universidade Federal Rural do Rio de Janeiro, Itaguaí, 185p

Instituto de Apoio à Pesquisa e ao Desenvolvimento Jones dos Santos Neves - IPES (2002) Informações municipais do Estado do Espírito Santo (1999-2000). Vitória. CD-ROM.

Gent JR JA, Ballard R, Hassan AE \& Cassel DK (1984) Impact of harvesting and site preparation on physical properties of piedmont Forest soil. Soil Science Society of American Journal, 48:173-177.

Gradwell MW (1960) Changes in the pore-space of a pasture topsoil under animal treading. New Zealand Journal of Agricultural Research, 4:663-674.

Lemos RC \& Santos RD (1996) Manual de descrição e coleta de solo no campo. 3 ed. Campinas, Sociedade Brasileira de Ciência do Solo. $84 \mathrm{p}$.

Lin HS, McInnes KJ, Wilding LP \& Hallmark CT (1999) Effects of soil morphology on hydraulic properties: I. Quantification of soil morphology. Soil Science Society of American Journal, 63:948-954.

Maki A, Kenji T, Kiyokazu K \& Teruo H (2007) Morphological and physico-chemical characteristics of soils in a steppe region of the Kherlen River Basin, Mongolia. Journal of Hydrology, 333:100-108

Menezes MD, Junqueira Júnior JÁ, Mello CR, Silva AM Curi N \& Marques JJ (2009) Dinâmica hidrológica de duas nascentes, associada ao uso do solo, características pedológicas e atributos físico-hídricos na sub-bacia hidrográfica do Ribeirão Lavrinha Serra da Mantiqueira (MG). Scientia Forestalis, 37:175-184.

Meirelles MCS \& Ribeiro LP (1995) Caracterização da sílica em horizontes coesos de solos de tabuleiros. In: $25^{\circ}$. Congresso Brasileiro de Ciência do Solo, Viçosa. Resumos expandidos, SBCS, UFV. p.1688-1689.

Naime UJ (1988) Caracterização de solos de terraços nas Zonas da Mata e Rio Doce, Minas Gerais. Dissertação de Mestrado. Universidade Federal de Viçosa, Viçosa, 76p.

Nunes WAGA, Ker JC, Schaefer CEGR \& Fernandes-Filho EI (2001) Relação solos paisagem e gênese de alguns solos do domínio dos mares de morros nas proximidades de Viçosa. Revista Brasileira de Ciência do Solo, 25:341-354.
Panoso L A (1976) Latossolo Vermelho Amarelo de tabuleiro do Espírito Santo. Tese de Livre Docência. Recife, Universidade Rural de Pernambuco, $115 \mathrm{p}$.

Reichert JM, Veiga M \& Cabeda MSVR (1992) Selamento superficial e infiltração de água em solos do Rio Grande do Sul. Revista Brasileira de Ciência do Solo, 16:289-298.

Resende M (1985) Aplicações de conhecimentos pedológicos à conservação de solos. Informe Agropecuário, 11:13-18.

Resende M, Lani JL, \& Rezende SB (1999a) Solo como reservatório dinâmico da produção de água. Ação Ambiental, 3:23-26.

Resende M, Curi N, Rezende SB \& Corrêa GF (1999b) Pedologia: base para distinção de ambientes. 3.ed. Viçosa, NEPUT. 338p.

Soil Moisture Corp (1991) Guelph Permeameter: Operating Instructions. Santa Bárbara.

Souza ZM \& Alves MC (2003) Movimento de água e resistência à penetração em um Latossolo Vermelho distrófico de cerrado, sob diferentes usos e manejos. Revista Brasileira de Engenharia Agrícola e Ambiental, 7:18-23.

Stolf R (1991) Teoria e teste experimental de fórmulas de transformação dos dados de penetrômetro de impacto em resistência do solo. Revista Brasileira de Ciência do Solo, 15:229-235.

Tormena CA \& Roloff G (1996) Dinâmica da resistência à penetração de um solo sob plantio direto. Revista Brasileira de Ciência do Solo, 20:333-339.

Universidade Federal de Viçosa - UFV (1984) Caracterização de solos e avaliação dos principais sistemas de manejo dos tabuleiros costeiros do Baixo rio Doce e da região norte do Estado do Espírito Santo e sua interpretação para uso agrícola. Viçosa, UFV. $153 \mathrm{p}$.

United States Department of Agriculture - USDA (2010). Keys to Soil Taxonomy, $11^{\mathrm{a}}$ ed. Soil Survey Staff. 338p.

Vzzotto, VR Marchezan E \& Segabinazzi T (2000) Efeito do pisoteio bovino em algumas propriedades físicas do solo de várzea. Ciência Rural, 30:965-969.

Whitting ng LD \& Allardice WR (1986) X-ray diffraction techniques. In: Klute, A., ed. Methods of soil analysis. 2.ed. Madison, WI, American Society of America. Pt.1, p.331-361. 